\title{
DESCRIPTIONS OF NEW SPECIES OF ORDOVICIAN FOSSILS FROM CHINA.
}

\author{
By Stuart Weller, \\ Of the University of Chicago, Chicago, Illinois.
}

The following new species of Ordovician brachiopods and trilobites were collected by the members of the Carnegie Institution Expedition to Eastern Asia in 1903-4. They are all from the Ki-sin-ling limestone at two localities near Su-kia-pa, in the province of Ssï-ch'uan, China. Locality $20 \mathrm{C}$ is in a gulch just northeast of Su-kia-pa, while locality $20 \mathrm{~B}$ is at the narrows of the Ta-ning River $1 \frac{1}{2}$ miles above the same place. The formation from which the fossils were secured is a dark, massive limestone 3,500 feet in thickness lying comformably upon subjacent beds of Cambrian age. The fossils are all from the uppermost layers of the formation, and in age are approximately equivalent to the fauna of the Trenton limestone of North America.

The types of the new species here described will be deposited in the United States National Museum on the completion of the fortheoming report of the Expedition to be published by the Carnegie Institution, in which work also illustrations of all the species will appear.

\section{Order BRACHIOPODA.}

PLECTORTHIS WILLISI, new species.

Description. - Shell transversely subelliptical in outline, the hinge line a little shorter than the greatest width, cardinal extremities slightly rounded. Pedicle valve depressed-convex, slightly compressed toward the cardinal extremities; the beak small, searcely incurved, cardinal area a little concave, sloping backward from the plane of the valve; cardinal margins angular. Brachial valve nearly as convex as the pedicle, compressed toward the cardinal extremities. Surface of each valve marked by from twenty to twenty-five major, radiating, rounded costæ, which increase in width conspicuously in passing from the beak to the front margin; in each interspace between these major costæ from one to three smaller ones which do not reach 
the beak are intercalated. The more minute surface markings are destroyed.

The dimensions of a pedicle valve are: Length, $7.5 \mathrm{~mm}$; width, 12 $\mathrm{mm}$.; height of area, $1 \mathrm{~mm}$.; convexity, $2 \mathrm{~mm}$.

Remarks. - The most notable feature of this shell is the conspicuous broadening of the major costæ in passing from the beak to the front margin.

The specific name is in honor of Mr. Bailey Willis, the leader of the Carnegie Expedition to China.

Formation and Locality.-Ki-sin-ling limestone, localities $20 \mathrm{C}$ and 20 B, near Su-kia-pa, province of Ssï-ch'uan.

\section{CLITAMBONITES CHINENSIS, new species.}

Description.--Shell broader than long, the hinge line straight, the greatest width at the hinge line or a little in front of it, the lateral and anterior margins describing a regular curve. Pedicle valve strongly elevated at the beak, the surface sloping from the umbo to the anterior and antero-lateral margins with a slightly convex curve, sometimes becoming a little concave as it approaches the anterior margin, the slope to the cardinal extremities somewhat more abrupt; cardinal area large, flat, sloping posteriorly from the hinge line in one specimen at an angle of $102^{\circ}$ and in another at an angle of $115^{\circ}$ to the plane of the valve, the cardinal margins sharp; delthyrium rather narrow, closed with a strongly convex deltidium, foramen terminal, encroaching upon the umbo; median septum inconspicuous; muscular impressions indefinite, rather large and flabelliform. Surface of each valve marked by fine radiating costæ, two or three of which occupy the space of one millimeter.

The dimensions of two pedicle valves are: Length, $15 \mathrm{~mm}$. and 14 $\mathrm{mm}$.; width, $18.7 \mathrm{~mm}$. and $16.9 \mathrm{~mm}$; height of cardinal area, $5 \mathrm{~mm}$. and $5 \mathrm{~mm}$.; greatest width of deltidium, $3 \mathrm{~mm}$. and $2.5 \mathrm{~mm}$. The dimensions of a brachial valve are: Length, $16.5 \mathrm{~mm}$.; width, $21 \mathrm{~mm}$.; convexity, $4 \mathrm{~mm}$.

Remarks. - This species is represented in the collection by only a small number of specimens, none of which are as well preserved as might be desired. It differs especially from other members of the genus in the terminal position of the pedicle opening, the pedicle apparently having passed through the foramen in a direction continuous with the surface of the deltidium and not at an angle to it, as is usually the case. Apparently this position of the pedicle also modified the position of the spondylium, its surface being nearly vertical to the inner surface of the valve, in consequence of which the median septum becomes essentially obsolete.

Formation and locality.-Ki-sin-ling limestone, localities $20 \mathrm{C}$ and 20 B, near Su-kia-pa, province of Ssï-ch'uan. 
HEMIPRONITES TENUISTRIATA, new species.

Description.--Shell wider than long, the valves subequally convex, the hinge line a little shorter than the greatest width, the cardinal extremities subangular. Pedicle valve most prominent on the umbo, the beak rather obtuse, the surface sloping from the umbo laterally and anteriorly with a gently convex curve; a slight, scarcely noticeable mesial flattening of the valve occurs toward the front, but no mesial sinus is present; cardinal area flat, rather large, with a broad deltidium, the cardinal margins angular. Brachial valve most prominent along the median line, but with no differentiated median fold, the greatest convexity at about the mid-length of the valve, the surface slightly compressed toward the cardinal extremities. Surface of each valve marked by exceedingly fine striæ, which are scarcely visible to the naked eye, about eight occupying the space of one millimeter.

The dimensions of a pedicle valve are: Length, $16 \mathrm{~mm}$; width, approximately $17.5 \mathrm{~mm}$.; convexity, $5 \mathrm{~mm}$.; height of cardinal area, $3 \mathrm{~mm}$.; length of hinge line, $15 \mathrm{~mm}$. The dimensions of a brachial valve are: Length, $17 \mathrm{~mm}$.; width, $22 \mathrm{~mm}$.; convexity, $5 \mathrm{~mm}$.

Remarks. - The specimens of this species in the collection are all too poorly preserved to allow the determination of its generic position with entire satisfaction. They have, however, the general form of European members of the genus Hemipronites, and it is believed that this generic reference is correct, but the nature of the deltidium and the presence or absence of a foramen can not be certainly determined. The genus Hemipronites has not been recognized in the American faunas, and is known especially from the Baltic provinces in Russia. The species is evidently congeneric with the shell which Martelli has called Orthisina giraldi a and the two species are closely aliied. The species here described, however, is somewhat more finely striate, and it seems to be relatively a somewhat broader shell.

Formation and locality.-Ki-sin-ling limestone, locality $20 \mathrm{C}$, near Su-kia-pa, province of Ssï-ch'uan.

\section{Order TRILOBITA.}

\section{AMPYX CHINENSIS, new spècies.}

Description.-Cranidium subsemicircular in outline, width $6.8 \mathrm{~mm}$., length $3.5 \mathrm{~mm}$. Glabella prominent, produced anteriorly somewhat beyond the frontal margin, subangular along the dorsal median line, the sides convex and sloping rather abruptly to the dorsal furrows; at the anterior termination of the glabella is the fractured base of a slender cylindrical spine whose length can not be determined, lateral furrows obsolete. Occipital furrow narrow and shallow. Occipital 
segment very short. The fixed cheeks are broad, convex, and subtriangular in outline, marked by post-marginal furrows, which continue from the extremities of the occipital furrow.

Remarks.--This species is a close ally of $A$. nasutus Dalman, but it differs from all illustrations of that species in its proportionally greater width. The thorax and pygidium have not been observed, the species being founded upon a single nearly perfect cranidium.

Formation and locality.-Ki-sin-ling limestone, locality $29 \mathrm{C}$, near Si-kia-pa, province of Ssï-ch'uan.

ASAPHUS BLACKWELDERI, new species.

Description.-Cranidium comparatively short and broad with the axis obsolete, obtusely angular in front, the palpebral lobes large and prominent, their anterior margins nearly opposite the middle point of the head; in front of the eyes the lateral margins diverge gradually to a point nearly halfway to the anterior margin, where they are rather broadly rounded, and then converge somewhat abruptly to the anterior extremity; back of the eyes the lateral margins diverge rapidly and curve backward to the posterior margin, the width of the cranidium along its posterior margin being considerably greater than the distance between the eyes. The occipital furrow and segment faintly developed. A slight median tubercle is situated at a point about halfway between the line joining the posterior extremities of the eyes and the posterior margin, aside from which the surface of the cranidium is apparently smooth.

A free cheek is associated with this cranidium and possibly belongs to the same species; its lateral region is differentiated as a rounded marginal border, and its genal angle is produced into a rather strong genal spine.

The dimensions of the cranidium described are: Length, $8 \mathrm{~mm}$; width between the eyes, $6 \mathrm{~mm}$. ; width along posterior margin, $7.5 \mathrm{~mm}$.

Remarks. - The outline of the cranidium upon which this species is established somewhat closely resembles that of $A$. expansus Dalman, the typical species of the genus, and both species are marked by a similar small median tubercle near the posterior margin. This Chinese species may be distinguished from its Europern ally, however, on account of the obsolete glabella. If the free cheek which occurs with A. blackwelderi really belongs to the species, this also will serve to distinguish the two forms by reason of its strongly developed genal spine, these spines being absent from the European species.

This new species is named in honor of Mr. Eliot Blackwelder, who collected the type specimens.

Formation and locality.-Ki-sin-ling limestone, locality $20 \mathrm{~B}$, near Si-kia-pa, province of Ssï-ch'uan. 
ASAPHUS TANINGENSIS, new species.

Description.-Cranidium rather long and slender, with the axis nearly obsolete; the palpebral lobes apparently rather small, situated back of the mid-length of the head. In front of the eyes the lateral margins of the cranidium describe the two sides of an ovate curve, gently diverging from the anterior extremities of the eyes, then broadly rounding and converging abruptly in front to the obtusely subangular anterior extremity; back of the eyes the lateral margins diverge abruptly with a gently convex curve to the posterior margin. Anteriorly the surface of cranidium is somewhat flattened to form an indistinct anterior limb. Occipital furrow and segment nearly obsolete. A faint median tubercle is situated on the median line of the head about halfway between the line joining the posterior extremities of the eyes and the posterior margin, but aside from this the surface of the cranidium is smooth.

The dimensions of the type specimen are: Length of cranidium, $11 \mathrm{~mm}$; width at posterior margin, $11.5 \mathrm{~mm}$; width between the eyes, $7 \mathrm{~mm}$.

Remarks.--This species is known only from the cranidium and it is of course possible that it should be correlated with some one of the species here described from the pygidium alone. The only one of these pygidia, however, which is recognized from exactly the same locality as this species, is A. lrvis, which is such a short form that it is not at all likely to be a portion of the same species as this elongate cranidium. The species should perhaps be referred to the genus Megalaspis rather than Asaphus, but this can not be determined from such incomplete material.

Formation and locality.-Ki-sin-ling limestone, locality $20 \mathrm{~B}$, near Su-kia-pa, province of Ssï-ch'uan.

ASAPHUS ASIATICUS, new species.

Description.--Pygidium subsemielliptical in outline, moderately convex, the axis depressed, bordered by rather broadly rounded axial furrows which become obsolete posteriorly; plural slopes prominent just outside the axial furrows, then sloping with a convex surface to the margins, without a differentiated marginal border. Axis occupying about one-third the total width of the pygidium anteriorly, tapering posteriorly to a bluntly rounded point, divided by rather broad and shallow, obscure furrows into twelve segments. Pleural slopes divided into about twelve obscure segments which reach less than half way from the axial furrows to the margins, the most anterior furrow crossing the plural slope is broad and deep, being much more conspicuous than those behind 
The dimensions of the type specimen, an incomplete pygidium, are: Length, $20.5 \mathrm{~mm}$.; width, about $30 \mathrm{~mm}$.; width of axis anteriorly, $10 \mathrm{~mm}$.; length of axis, $16 \mathrm{~mm}$.

Remarks. - This species is known only from the pygidium which is much like that of the European $A$. expansus, being distinguished chiefly by its greater proportional length and by the more obscure segmentation.

Formation and locality.-Ki-sin-ling limestone, locality $20 \mathrm{C}$, near Su-kia-pa, province of Ssï-ch'uan.

ASAPHUS L $Æ V I S$, new species.

Description.-Pygidium nearly semicircular in outline. The axis depressed, without segmentation, poorly defined by the nearly obsolete axial furrows, occupying about one-fourth of the total width of the pygidium anteriorly; pleural slopes smooth, without segmentation, convex toward the axis but becoming depressed in a broad, moderately concave marginal border toward the outer margin. The posterior extremity of the axis reaching the inner margin of the concave border.

The dimensions of the type specimen are: Length, $12 \mathrm{~mm}$; width, $23 \mathrm{~mm}$.; width of axis anteriorly, $5.5 \mathrm{~mm}$; length of axis, $8.5 \mathrm{~mm}$.; width of concave marginal border, about $3.5 \mathrm{~mm}$.

Remarks. - This species is represented in the collection by a single nearly complete pygidium. So far as can be determined, it seems to be a member of the genus Asaphus in its strict sense, the species being especially characterized by its remarkably smooth surface.

Formation and locality.-Ki-sin-ling limestone, locality $20 \mathrm{~B}$, near Su-kia-pa, province of Ssï-ch'uan.

ASAPHUS CHINENSIS, new species.

Description.-This species is founded upon a single nearly perfect pygidium and is much like the last-described form. It differs in its proportions, however, its dimensions being: Length, $14 \mathrm{~mm}$; width, $22.5 \mathrm{~mm}$; ; width of axis anteriorly, $6.8 \mathrm{~mm}$.; length of axis, $9.5 \mathrm{~mm}$.; width of concave marginal border, about $4 \mathrm{~mm}$. The most marked differences between the two species is the much more conspicuous concave border in $A$. chinensis and in the slight though obscure traces of segmentation upon both the axis and the pleural slopes. This latter character, however, may be due to the removal of the test from the central portion of the specimen, and if the external surface were preserved it might be as smooth as A. lævis.

Formation and locality. - Ki-sin-ling limestone, locality $20 \mathrm{C}$, near Su-kia-pa, province of Ssï-ch'uan. 
MEGALASPIS MINOR, new species.

Description.-Pygidium small, subelliptical in outline. Axis scarcely elevated above the general surface, about one-third of the total width of the pygidium anteriorly, tapering to the rather bluntly rounded posterior extremity, divided by nearly obsolete depressions into eight or nine obscure segments. Pleural slopes regularly convex from the sides of the axis to the margins, without a differentiated marginal border, marked by about six narrow, faint, grooved segments which reach halfway across the slopes. Anteriorly, close to the margin and parallel with it a subangular groove extends from each side of the axis about halfway across the pleural slopes; in front of and outside the lateral extremities of these grooves the surface is abruptly compressed.

The dimensions of the type specimen are: Approximate length, $9 \mathrm{~mm}$.; width, $14.5 \mathrm{~mm}$.; width of axis anteriorly, $4.8 \mathrm{~mm}$.; length of axis, $7 \mathrm{~mm}$.

Remarks. - This species is known only from the pygidium, and even that portion is incomplete. It is referred to the genus Megalaspis by reason of the grooved pleural segments. The segmentation is very faint and would probably be even less distinct or perhaps obsolete entirely were the test of the specimen preserved.

Formation and locality.- Ki-sin-ling limestone, locality 20 B, near Su-kia-pa, province of Ssï-ch'uan.

ILLAENUS? BRONTEOIDES, new species.

Description.-Pygidium subsemicircular in outline, flattened on top. Axis ill defined, unsegmented, occupying a little less than one-third the total width of the pygidium anteriorly, very slightly elevated in front and merging into the general surface of the pygidium posteriorly. Pleural slopes flattened on each side of the axis, sloping to the margins exteriorly with a slightly concave curve. The surface of each pleural slope, when the test is removed, is marked by about twelve or thirteen very narrow and scarcely elevated ribs, which are grooved longitudinally and extend from the indefinite axial furrows about to the line where the surface begins its more abrupt slope to the lateral margins.

The dimensions of the type-specimen are: Length, $8.5 \mathrm{~mm}$; width, $14.8 \mathrm{~mm}$.; width of axis anteriorly, $4.5 \mathrm{~mm}$.

Remarks. - This species is represented by a single specimen in the collection, a nearly complete pygidium. It is a peculiar form, having the general contour of an lllænus, but with the pleural slopes faintly segmented, suggesting the genus Bronteus. These segments are very faint, however, and would possibly not be visible at all were the specimens completely covered with the test.

Formation and locality.-Ki-sin-ling limestone, locality $20 \mathrm{C}$, near Su-kia-pa, province of Ssï-ch'uan. 


\section{$2 \mathrm{BHL}$ Biodiversity Heritage Library}

Weller, Stuart. 1907. "Descriptions of new species of Ordovician fossils from China." Proceedings of the United States National Museum 32(1549), 557-563. https://doi.org/10.5479/si.00963801.1549.557.

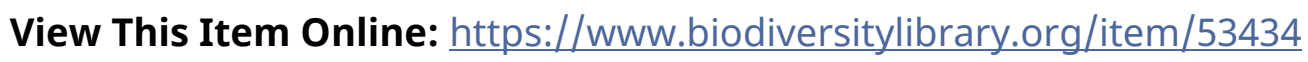

DOI: https://doi.org/10.5479/si.00963801.1549.557

Permalink: https://www.biodiversitylibrary.org/partpdf/51895

\section{Holding Institution}

Smithsonian Libraries

\section{Sponsored by}

Smithsonian

\section{Copyright \& Reuse}

Copyright Status: Public domain. The BHL considers that this work is no longer under copyright protection.

This document was created from content at the Biodiversity Heritage Library, the world's largest open access digital library for biodiversity literature and archives. Visit BHL at https://www.biodiversitylibrary.org. 